The Art of English Poesy 



\title{
The Art of
}

English Poesy

by George Puttenham

A Critical Edition

\author{
Edited by \\ Frank Whigham \\ and Wayne A. Rebhorn
}

Cornell University Press

ITHACA AND LONDON 
Publication of this book was made possible, in part, by a University Cooperative Society Subvention Grant awarded by The University of Texas at Austin.

\section{Copyright $@ 2007$ by Cornell University}

All rights reserved. Except for brief quotations in a review, this book, or parts thereof, must not be reproduced in any form without permission in writing from the publisher. For information, address Cornell University Press, Sage House, 5 I 2 East State Street, Ithaca, New York I485O.

First published 2007 by Cornell University Press

First printing, Cornell Paperbacks, 2007

Printed in the United States of America

\section{Library of Congress Cataloging-in-Publication Data}

Puttenham, George, d. I590.

[Arte of English poesie]

The art of English poesy : contrived into three books : the first of poets and poesy, the second of proportion, and the third of ornament (London, I589) / by George Puttenham ; edited by Frank Whigham and Wayne A. Rebhorn. A critical ed.

p. cm.

Generally attributed to George Puttenham; has also been attributed to Richard Puttenham and to John, Baron Lumley.

Includes bibliographical references and index.

ISBN 978-0-80I4-3758-8 (cloth : alk. paper) — ISBN 978-o-80I4-8652-4 (pbk. : alk. paper)

I. Poetry-Early works to I80o. 2. English poetry-History and criticism.

I. Puttenham, Richard, I 520?-I60I? II. Lumley, John Lumley, Baron, I 534?-I609. III. Whigham, Frank. IV. Rebhorn, Wayne A., I943- V. Title.

PNIO3I.P8 2007

$821.009-\mathrm{dc} 22$

Cornell University Press strives to use environmentally responsible suppliers and materials to the fullest extent possible in the publishing of its books. Such materials include vegetable-based, low-VOC inks and acid-free papers that are recycled, totally chlorine-free, or partly composed of nonwood fibers. For further information, visit our website at www.cornellpress.cornell.edu.

Cloth printing Io 98765432 I

Paperback printing Io 987765432 I 
For Jo AnNe

AND

Marlette 
